Cárdenas, S., L. Cardona, M. A. Echeverry-Galvis, and P. R. Stevenson. 2020. Movement patterns and habitat preference of Oilbirds (Steatornis caripensis) in the southern Andes of Colombia. Avian Conservation and Ecology 15(2):5. https://doi.org/10.5751/ACE-01564-150205

Copyright (C) 2020 by the author(s). Published here under license by the Resilience Alliance.

Research Paper

\title{
Movement patterns and habitat preference of Oilbirds (Steatornis caripensis) in the southern Andes of Colombia
}

\author{
Sasha Cárdenas ${ }^{1,2}$, Laura M. Cardona ${ }^{1}$, Maria A. Echeverry-Galvis ${ }^{2}$ and Pablo R. Stevenson ${ }^{1}$ \\ ${ }^{1}$ Laboratorio de Ecología de Bosques Tropicales y Primatología, Departamento de Ciencias Biológicas, Universidad de Los Andes, \\ Bogotá, Colombia, ${ }^{2}$ Departamento de Ecología y Territorio, Facultad de Estudios Ambientales y Rurales, Pontificia Universidad \\ Javeriana, Bogotá, Colombia
}

\begin{abstract}
Habitat use and movement patterns in animals are usually determined by the availability of food, morphological and physiological traits, social systems, and safe sites to complete vital cycles. The objective of this study was to estimate the home-range area, daily traveled distance, and patterns of space use by Oilbirds (Steatornis caripensis), and the factors that can affect them in Cueva de Los Guacharos National Park (Huila, Colombia). We attached GPS devices to five individuals and recovered information from three. Home ranges were estimated by minimum convex polygon (MCP), 95 and 50\% kernel methods. Traveled distances were estimated as the sum of the linear distances between sampling points (every $30 \mathrm{~min}$ ), and patterns of habitat use were evaluated through ecologicalniche factor analysis (ENFA), including forest cover, altitude, and degree of fragmentation. Analysis of habitat preference was done using 25 vegetation plots established in frequently used areas and species richness, and the proportion of consumed plants was compared with other locations within their distribution range. Home-range area was estimated to be $4517 \mathrm{~km}^{2}$, possibly an underestimation due to reduced sample size. The average traveled distance per night was $55 \mathrm{~km}$ (range: $0-112 \mathrm{~km}$ ). Analyses of habitat use showed a clear preference for areas with higher forest cover. Height above sea level was also largely associated with frequencies of habitat use, indicating a low use of areas above $3000 \mathrm{~m}$, while the degree of fragmentation was not a strong predictor of habitat use. Finally, vegetation plots in frequently used areas showed a higher abundance of fruiting trees consumed by Oilbirds than control plots. Overall, Oilbirds have amazing movement capacity, being able to use distant landscape elements, and showing a clear preference for areas with forest cover, lower altitude, and areas with a high representation of the plant species they consume.
\end{abstract}

\section{Habitudes de déplacement et préférence en matière d'habitat des Guacharos des cavernes (Steatornis caripensis) dans les Andes du sud de la Colombie}

RÉSUMÉ. L'utilisation de l'habitat et les habitudes de déplacement chez les animaux sont généralement dictées par la disponibilité de ressources alimentaires, les traits morphologiques et physiologiques, les systèmes sociaux et les sites sécuritaires pour compléter les cycles de vie. L'objectif de cette étude était de calculer la superficie du domaine vital, les distances parcourues quotidiennement et les profils d'utilisation spatiale des Guacharos des cavernes (Steatornis caripensis), et cerner les facteurs qui peuvent agir sur eux dans le parc national Cueva de Los Guacharos (Huila, Colombie). Nous avons posé des unités GPS sur cinq individus et avons obtenu des informations sur trois d'entre eux. Les domaines vitaux ont été calculés au moyen des méthodes du polygone convexe minimum (MCP) et des kernels à 95 et à $50 \%$. Les distances parcourues ont été calculées en sommant les distances linéaires entre les points d'échantillonnage (toutes les $30 \mathrm{~min}$ ), et les profils d'utilisation de l'habitat ont été établis par l'analyse des facteurs de niche écologique (ENFA), y compris le couvert forestier, l'altitude et le degré de fragmentation. L'analyse des préférences en matière d'habitat a été réalisée en inventoriant les espèces végétales dans 25 parcelles réparties dans des endroits fréquemment utilisés, et la proportion des plantes y ayant été consommées a été comparée avec celle d'autres endroits situés dans leur aire de répartition. Le domaine vital a été établi à $4517 \mathrm{~km}^{2}$, sans doute une sous-estimation en raison de la faible taille de l'échantillonnage. La distance moyenne parcourue par nuit était de $55 \mathrm{~km}$ (étendue : 0-112 km). Les analyses de l'utilisation de l'habitat ont montré une nette préférence pour les endroits avec un couvert forestier dense. L'altitude au-dessus du niveau de la mer était aussi grandement associée avec la fréquence d'utilisation de l'habitat, les endroits au-dessus de 3000 m étant peu utilisés, alors que le degré de fragmentation ne s'est pas avéré une bonne variable explicative de l'utilisation de l'habitat. Finalement, les parcelles de végétation dans les endroits fréquemment utilisés avaient une abondance plus grande d'arbres fruitiers consommés par les guacharos que les parcelles témoin. Dans l'ensemble, les Guacharos des cavernes ont une capacité de déplacement incroyable, étant capables d'utiliser des éléments distants du paysage, et montrent une préférence certaine pour les endroits offrant couvert forestier, faible altitude, et abondance des espèces végétales qu'ils consomment.

Key Words: birds; daily travel distance; habitat use; home range; movement ecology

Address of Correspondent: Sasha Cárdenas, Laboratorio de Ecología de Bosques Tropicales y Primatología, , Departamento de Ciencias Biológicas,, Universidad de Los Andes, Carrera 1 No.18A-10, , Bogotá, Colombia., sashacaho@gmail.com 


\section{INTRODUCTION}

For animals with the capacity of individual movement, their location in space usually depends on habitat characteristics, including a wide range of ecological factors (Nathan 2006, Scharf et al. 2018). Among the most important is the availability of nutritional resources, adequate zones to carry out reproductive events, and places with low predation risk (Fahrig 2007, Gillies and St. Clair 2010). Other parameters included in the study of movement consider topographic elements along the trajectory, travel length, and the ability to use different habitat types (Andrén 1994, Fritz et al. 2003, Frair et al. 2005). The relevance of these limiting factors is variable depending on the species (Villard et al. 1999, Johnson et al. 2002, Fritz et al. 2003) because movement capacity in birds depends on traits such as morphology, diet, foraging behaviors, body size, and habitat specialization (Neuschulz et al. 2013, Díaz Vélez et al. 2015). The most extreme cases of long-distance movement have been reported for birds that migrate from pole-to-pole (Gill et al. 2008). Still, some frugivorous species such as hornbirds, quetzals, and toucans travel long distances to find food resources that are unevenly distributed (Symes and Marsden 2007, Holbrook 2011, Mueller et al. 2014, Díaz Vélez et al. 2015). On the other hand, species such as some passerine birds, from the Furnariidae family, are incapable of crossing between forest fragments or barriers such as rivers because their movement is strongly limited by open areas (Hayes and Sewlal 2004). Therefore, anthropogenic factors such as fragmentation, edge-effects, and changes in the matrix have a heavy impact on some species (Hobbs and Yates 2003), and their movement patterns can be affected depending on factors such as fragment connectivity and size (Gobeil and Villard 2002, Gillies and St. Clair 2010, Herrmann et al. 2016). This could lead, in a cascading effect, to alterations in some ecosystem processes that depend on movements, such as seed dispersal and the movement of nutrients (Howe and Smallwood 1982, Holbrook and Smith 2000, Gosper et al. 2005, Levey et al. 2005, Stevenson and Guzmán-Caro 2010). Therefore, knowledge on how landscape changes can affect these processes is important for the conservation of populations, their interactions within communities, and ecosystem processes (Holland et al. 2009, Gillies and St. Clair 2010, Maniguaje et al. 2011).

Oilbirds (Steatornis caripensis) are nocturnal frugivorous birds distributed in the Neotropics (southern Central America, northern South America, and the tropical Andes). During the day, these birds usually sleep inside caves and canyons of both lowland and montane forests, and during the night, they travel long distances (Roca 1994, Thomas 1999, Bosque 2002, Tello et al. 2008, Holland et al. 2009). Foraging patterns in Oilbirds have only been studied in Venezuela, showing that the farthest distances from the cave are on average $44 \pm 10.7 \mathrm{~km}$ (Holland et al. 2009). Oilbirds feed on fruits of numerous plant species (Tannenbaum and Wrege 1978, Bosque and de Parra 1992, Bosque 2002, Rojas-Lizarazo 2016, Stevenson et al. 2017), swallowing the entire fruit and digesting the pulp to later expel whole seeds in feces or through regurgitation (Bosque and de Parra 1992, Amico and Aizen 2005). Therefore, these birds have the potential of being important vectors for long-distance seed dispersal between isolated fragments (Holland et al. 2009, Karubian et al. 2012a, Stevenson et al. 2017) and could be keystone species for regeneration processes in fragmented forests.
However, little is known about this species' habitat requirements outside their caves, or about the availability of appropriate areas for them within the landscape.

The objective of this study was to determine which factors, at a landscape level such as cover types, degree of fragmentation, plant diversity, and tree composition are associated with habitat use by Oilbirds. Additionally, the home range, daily traveled distance, and flight speed of three individuals were estimated. The information on habitat use was used to understand which landscape configuration can lead to the maintenance of the Oilbirds' movement patterns (Holland et al. 2009, Rojas-Lizarazo 2016). It was hypothesized that the Oilbirds would prefer the use of coverage that provides food resources and places to complete their life cycles. We also expected that at the landscape scale, they would use more often elevations near the main cave (1500-2500 masl), places with greater forest cover to find feeding trees, and would be indifferent to fragmentation given the long flight distances so far reported (Holland et al. 2009). On a local scale, it was expected that the abundance of plants consumed would be higher in frequently used areas than in control areas (i.e., where they have not been reported).

\section{METHODS}

\section{Study area}

The study area was defined as the minimum rectangle (ca. 8000 $\mathrm{km}^{2}$ ) enclosing all known movements of the colony of Oilbirds in the southern Andes of Colombia (Fig. 1). The studied Oilbirds based their activities in the main cave at Cueva de Los Guacharos National Park (NP), but their moving ranges included three additional national parks (Alto Fragua Indi Wasi, Serranía de los Churumbelos, and Puracé), regional reserves, private farms, and some urban areas. The main cave, in which nesting takes place, is located at 2000 masl (Fig. 1). The forests at Guacharos NP are classified into three groups: sub-Andean forests located between 1100 and 2400 masl, which include primary and secondary forests; Andean forests, located from 2400 to 2700 masl; and subparamo above 2700 masl (MINAMBIANTE 2005). At least 74 families of woody plants have been found in the park (Prada and Stevenson 2016). Also, there are forests dominated by oak trees, which are distributed in the upper limit of sub-Andean forests and the lower limit of Andean forests (MINAMBIENTE 2005).

\section{Data collection}

GPS telemetry devices of approximately 23 gm (e-obs GPS-Tags WGS84-Height, Global Positioning System of e-obs digital telemetry (C) were attached to five individuals Oilbirds captured at the main cave of Cueva de Los Guacharos NP. The devices generate radio wave transmissions at a specific radio frequency that were received with a Yagi-Uda-antenna (provided with the devices for that specific task) in the cave, allowing the downloading of the data. GPS tags corresponded to approximately $6 \%$ of the individual's body weight (mean body weight $=419 \mathrm{gm}$; Holland et al. 2009) and were attached to the back of the birds through a harness-type system using an elastic thread of $0.6 \mathrm{~mm}$ wide, which surrounded the individual's wings and the chest in a T form (Roshier and Asmus 2009). Devices were located close to the individual's center of gravity, so that the installation would not affect their mobility. Captures were 
performed using mist nets in the cave's entrance during two different seasons. Birds of unknown sex greater than $200 \mathrm{gm}$ were selected. Devices labeled G29 and G30 were installed in the nonbreeding season, beginning data collection on December 2015; and devices G31, G32, and G33 were placed during the breeding season, beginning data collection on March 2016. Data were recovered for 3 out of 5 individuals: 56 and 31 nights were sampled for devices $\mathrm{G} 32$ and G33, respectively, and 17 nights were sampled for device number G29. Two Oilbirds in the nonbreeding period provided no data because they did not return to the cave, at least when we downloaded data at proximity. Even with low sample sizes for both the nonbreeding and the breeding season, we present some data separately. Information on location (WGS-84), flight speed, elevation, and flight direction were collected for each bird at 30-minute intervals, from 18:00 to 6:00 $\mathrm{h}$ COT. A total of 2266 records were obtained for the 3 individuals, of which $29 \%$ reported coordinates and speeds of zero. Because the GPS signal is lost within the cave, coordinates of the cave were assigned when the trajectory showed an approach to that point. All location data generated by the telemetry devices were converted to UTM (universal transverse mercator) coordinates.

Fig. 1. Study area and the location of Cueva de Los Guácharos National Park in which the Oilbird colony under study was located.

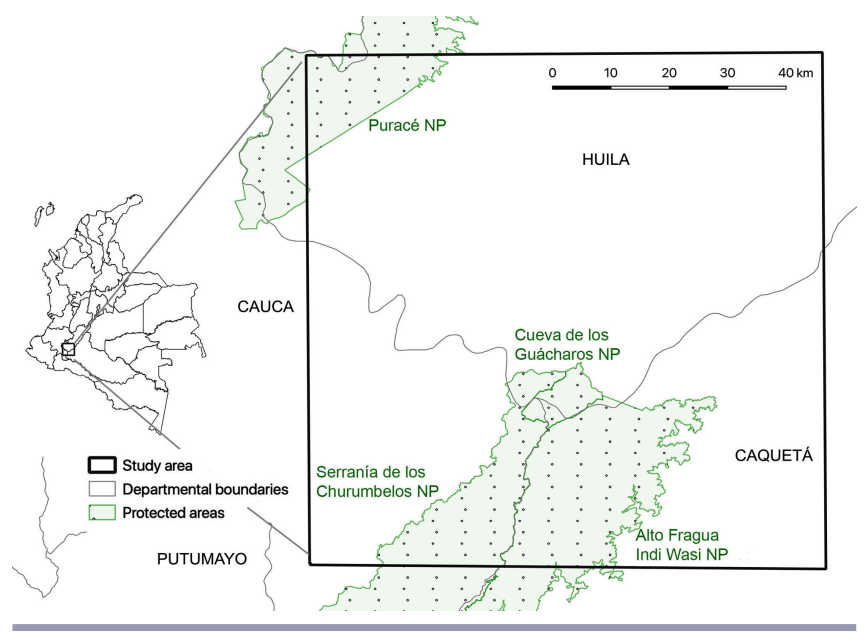

\section{Home range and movements}

The home range was estimated for each individual and all three, using 100\% minimum convex polygon (MCP) because it allows comparisons with other studies. Also, within the home range established for each individual, a grid $(5 \times 5 \mathrm{~km})$ was built to estimate the number of times a quadrat was used and thus determine if the cumulative sampling effort per individual was sufficient. Furthermore, Kernel UD analyses were performed to estimate the home-range size of the studied individuals, using $95 \%$ and $50 \%$ of probability of spatial occurrence as indicators of the total range and core areas, respectively. The home ranges were estimated and visualized using the extension Spatial Analysis for ArcGIS 10.3 and R software, using the package adehabitatHR (Calenge 2006, 2011, R Development Core Team 2012). Daily straight-line distances were calculated as the sum of the linear distances between sampling points every 30 minutes. Flight-speed data were downloaded as instantaneous samples (not calculated from a distance moved over time between consecutive GPS locations) to establish at which time of the night individuals used different movement patterns, indicating the hours when the Oilbirds engaged in fast or slow movements. Kruskal-Wallis tests were used to examine differences in flight speed between individuals and night hours.

\section{Landscape elements and habitat use}

Geographic information analyses were performed with the software QGis, ArcGis, and the packages raster, rgdal, sp, and gdistance in R (Pebesma and Bivand 2005, Hijmans and van Etten 2014, Bivand et al. 2016, OSGEO 2018). A vegetation map was generated to define the different habitat types available for the Oilbirds, including those known to be used by the species in previous studies (Snow 1961, Tannenbaum and Wrege 1978, Roca 1994, Bosque et al. 1995, Bosque 2002, Holland et al. 2009, Karubian et al. 2012a). Following CORINE land-cover classification, habitat types were grouped as (1) dense forest, (2) fragmented or disturbed forest, (3) coffee plantations, (4) mosaic of crops and natural forest, (5) mosaic of grass with natural forest, (6) pastures and crops, (7) burnt zones, naked, and degraded lands, (8) rivers and lagoons, (9) secondary vegetation, (10) shrublands, (11) forest plantations, and (12) urban zones. Additionally, the central cave was included as a cover category to avoid overestimating the use of dense forest, in which the main cave is located.

To identify which variables affect the frequency of habitat use, an ecological-niche factor analysis (ENFA) was performed using the package dehabitatHS in R 3.4.1, which estimates the degree of marginality and specialization using data on presence relative to the habitat availability in the study area $\left(7.961 \mathrm{~km}^{2}\right)$. Marginality is defined as the environmental distance between the species' optimum and available habitat, and specialization is the relationship between the ecological variance of the habitat and that of the species. In other words, specialization is opposite to tolerance and suggests how specialized individuals can be to specific variables (Hirzel et al. 2002). The following factors were used as explanatory variables: forest cover (percentage of trees per pixel, $30 \times 30 \mathrm{~m}$, in raster format; Hansen et al. 2013), height above sea level from a digital model of elevation (Amatulli et al. 2018), and degree of fragmentation, associated to the degree of continuity between the forest fragments in the study area, obtained from the forest cover map. To quantify the degree of fragmentation $(F)$ four parameters were used: $n=$ the quantity of cells with forest cover within the analysis window; $c=$ the number of cells that have at least another contiguous cell with forest cover, meaning that it shares one of its sides completely; $g=$ the number of groups of cells of the forest cover that are formed within the window; and $N=$ the total number of cells. From these data, a fragmentation index was estimated according to González-Caro and Vasquez (2017) with values of zero when fragmentation is high and values close to one when fragmentation is low.

$$
\mathrm{F}=\frac{n c+n}{g N^{2}}
$$

From these analyses, a raster is obtained, indicating the index of fragmentation for every pixel, and then used as a niche factor. The analysis was performed with 999 random data replicates. To 
test for spatial pseudoreplication, an estimation of Moran's Index 1 was included (Dutilleul et al. 1993).

\section{Influence of vegetation}

To evaluate if plant diversity and the proportion of species consumed by Oilbirds are associated with habitat use frequency, a comparison was made between the characteristics of the most frequently used areas by the individuals equipped with the tracking devices, and other plots in which Oilbirds were not reported. Frequently used areas $(\mathrm{N}=30)$ were selected based on a high number of independent visits (more than 6). The minimum distance between sites was $300 \mathrm{~m}$ to avoid spatial pseudoreplication. A total of 25 locations were surveyed because of accessibility and security.

At each of the frequently used locations, 0.1 ha circular vegetation plots were established in which all trees, palms, and lianas with a diameter at breast height $(\mathrm{DBH})>10 \mathrm{~cm}$ were marked, identified, and measured. Because GPS points can have between 2-5 m of error, circular plots were established to increase the chance of including feeding trees. A GPS fix was taken as the center of the plot, and vegetation within $20 \mathrm{~m}$ was sampled. These plots in the frequently used locations were compared with plots within the PNN Cueva de Los Guacharos, other places in the south of Huila, and in the foothills of Caquetá, that were within the sampling window (Fig. 1), but with no reports of visits by Oilbirds. These plots were taken as controls $(\mathrm{N}=46)$, even though it cannot be guaranteed that these are zones are not used by the Oilbirds, and their location was determined to represent the floristic composition of different forest types in the region (e.g., Prada and Stevenson 2016).

The DBH and the species (or morphospecies) were recorded for each plant within plots. Based on secondary literature, plant species potentially consumed by the Oilbirds of the PNN Cueva de Los Guacharos were determined (i.e., all species from the Lauraceae family, various palms such as Euterpe precatoria, Prestoea acuminata, Geonoma undata, Oenocarpus spp., Socratea exhorrhiza, Aiphanes horrida, and Chamaedorea linearis; and few other plants in the genera: Dacryodes, Trattinnickia, Dendropanax, Turpinia, Guarea, Viburnum, and Symplocos). The number of individuals of the potentially consumed species was registered, as well as their proportion in each plot, and the proportion of their basal area (BA) estimated from $\mathrm{DBH}$ measurements. To estimate the diversity of plants in each plot, species richness was determined as the index of species per stem, correcting the richness value for the number of individuals (Hubbell et al. 1999), which was highly variable (8-281). In fact, fewer individuals were found in frequently used areas than in control plots $\left(\right.$ ANOVA $_{1.69}=27, \mathrm{p}<0.001$; Appendix 1, Table A1.1). The number of species per stem, the number of individuals of consumed species, their proportion, and basal area were compared between frequently used and control sites using ANOVA tests, given the parametric nature of the data.

\section{RESULTS}

\section{Home range and movements}

According to the MCP, the three Oilbirds occupied a home range of at least $4517 \mathrm{~km}^{2}\left(580.6 \mathrm{~km}^{2}\right.$ for individual $\mathrm{G} 29,1866.8 \mathrm{~km}^{2}$ for individual G32, and $2295.5 \mathrm{~km}^{2}$ for individual G33), whereas the 95 and $50 \%$ kernel were $2567.9 \mathrm{~km}^{2}$ and $481.7 \mathrm{~km}^{2}$, respectively. However, for all three individuals, rarefaction curves showed that the sampling effort was not enough to obtain a reliable estimation of the home-range area (Fig. 2), which suggests more extensive ranges. The individual sampled in the nonbreeding season spent more days outside the cave (58\%) than those tracked during the breeding season ( 6 to $17.6 \%$ of days outside the cave), which also tended to remain closer to the cave than the other birds. Core areas included the region around the cave and grouped points in foraging areas separated by a maximum distance of $40.7 \mathrm{~km}$ (Fig. 3), which agrees with the Moran Index indicating spatial clustering.

Fig. 2. Rarefaction curves indicating the number of quadrats used by three Oilbirds as function of the cumulative sampling days in the PNN Cueva de Los Guácharos (Huila, Colombia). Values for G29 are shown in red (nonbreeding season), for G32 in green, and for G33 in blue.

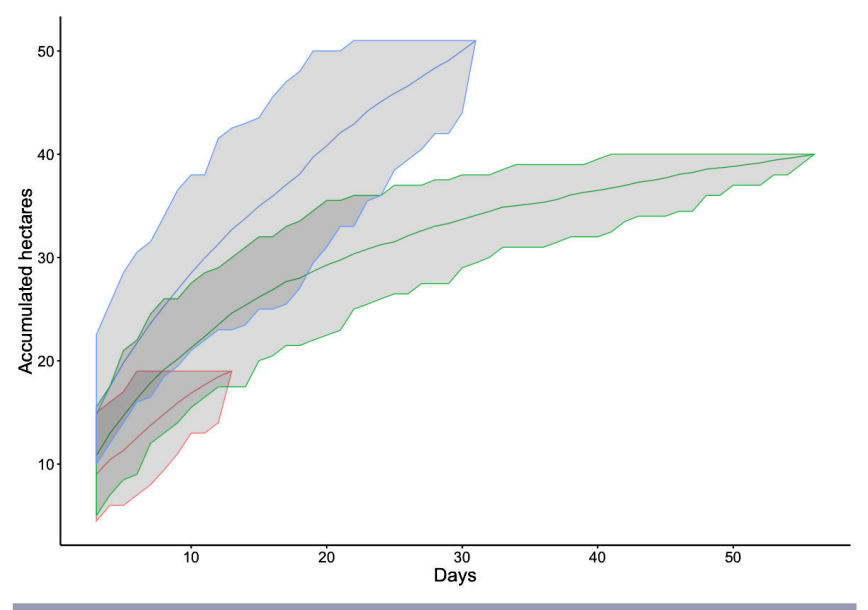

Fig. 3. Estimated home range for the Oilbirds studied in the PNN Cueva de Los Guácharos (Huila, Colombia), according to Kernel estimates of $95 \%$, blue; and $50 \%$, purple. Points correspond to the locations of instantaneous records every 30 minutes, and the green triangle represents the cave in which birds were captured and fitted with GPS tags.

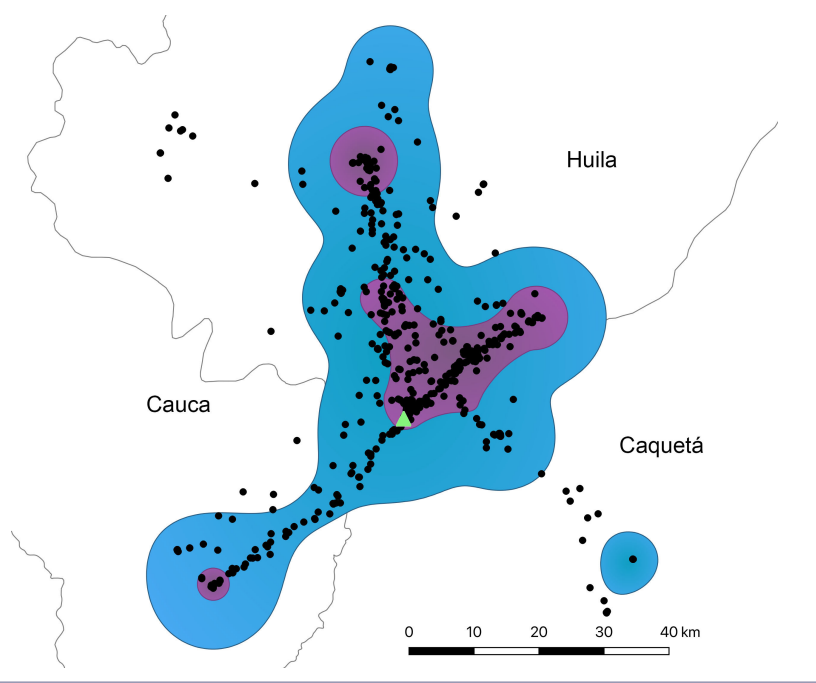


Fig. 4. Boxplots of instantaneous flight speed recorded during night hours for three Oilbirds captured in PNN Cueva de Los Guácharos (Huila, Colombia): (a) Oilbird G29 (nonbreeding season), (b) Oilbird G32, and (c) Oilbird G33.
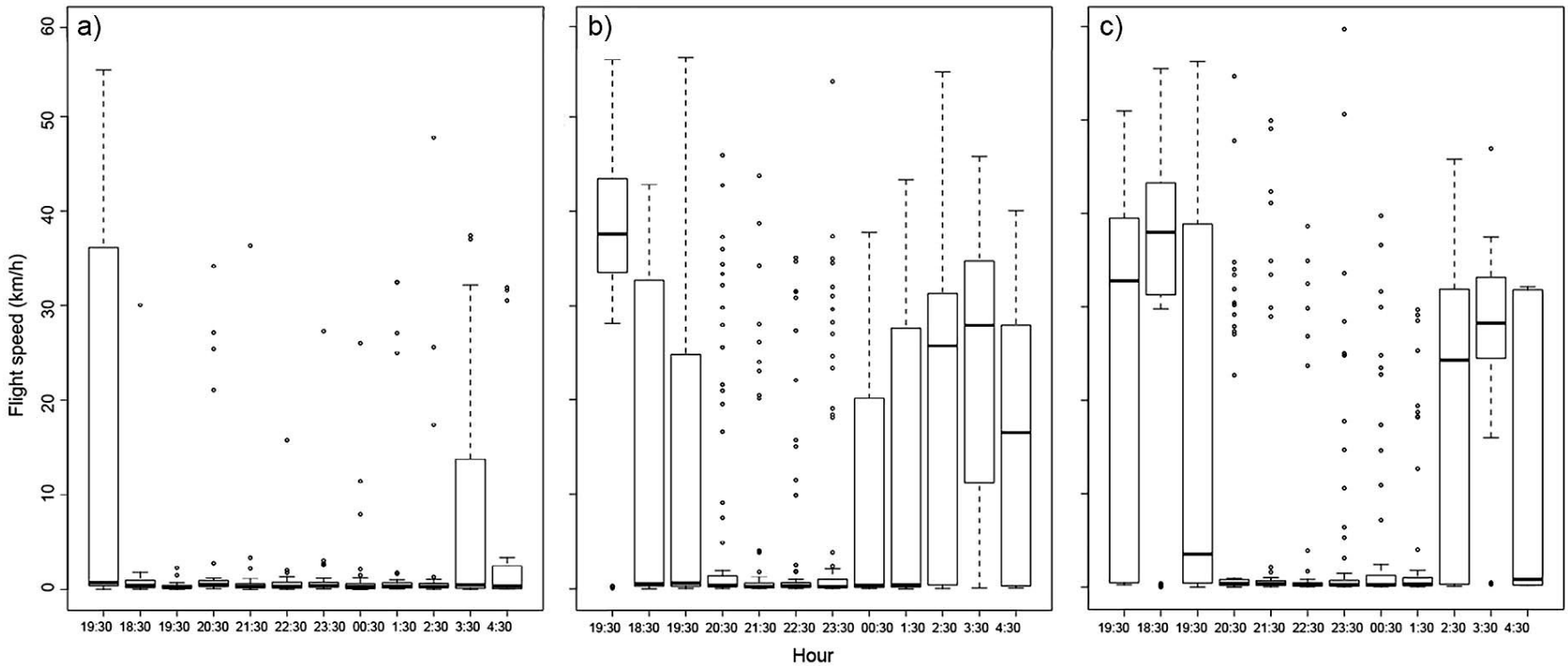

The most distant point from the cave was located at $58.2 \mathrm{~km}$. Tracked Oilbirds moved on average $54.7 \mathrm{~km}$ per night, ranging from an average of $19.0 \mathrm{~km}$ (nonbreeding season) to 52.0 and 79.1 $\mathrm{km}$ (individuals tagged during the breeding season; Appendix 1, Table A1.2). Maximum flight distances per night were of 101.3 and $112.4 \mathrm{~km}$ for individuals monitored during the breeding season, and $48.2 \mathrm{~km}$ for the individual monitored in the nonbreeding season. Oilbirds monitored during the reproductive season did not move away from the cave some nights, whereas the minimum flight distance for the other individual was $0.9 \mathrm{~km}$.

The mean overall movement speed was $9.2 \mathrm{~km} / \mathrm{h}$ (including travel and foraging speeds), but the maximum speeds registered were between 54.9 and $59.7 \mathrm{~km} / \mathrm{h}$ (Appendix 1, Table A1.3). In general, higher movement speeds were recorded at the beginning and at the end of the night $\left(\mathrm{X}^{2}=197.9\right.$, df $=11, \mathrm{P}<0.0001$; Fig. 4$)$. The Oilbird sampled in the nonbreeding period showed the lowest speeds (Appendix 1, Table A1.3).

\section{Landscape elements and habitat use}

The most frequently used area was the cave ( $28 \%$ of the records), followed by dense forest $(21 \%)$, a mosaic of crops and natural vegetation $(15 \%)$, and coffee plantations $(12 \%)$. The available places that did not show records included urban zones, exotic tree plantations, shrublands, and degraded, burnt, and exposed soils.

According to ENFA, there was a marginality of 0.3 (axis $\mathrm{X}$ in Fig. 5A), indicating that the monitored Oilbirds used specific places relative to the available habitat within the study window. Specialization (axis $\mathrm{Y}$ in Fig. 5A) was 4.09, showing that the variance of the available habitat was four times higher than the variance of used habitat. Considering the computation of the marginality and the specialization, there was a significant difference between the areas used and the available habitat $(\mathrm{P}=$ 0.001 , Fig 5A). Results showed that the most influential variables of habitat use were elevation and tree cover, which showed high levels of specialization and showed tolerance to fragmentation (axis $\mathrm{Y}$ in Fig. 5A). There was a preference for the use of intermediate elevations of $1000-2000 \mathrm{~m}$, compared to the 200-3500 $\mathrm{m}$ range available in the study area (Fig. 5Ba), showing intolerance to altitudes with no birds visiting elevations above $3000 \mathrm{~m}$. Similarly, they chose areas with high tree cover (Fig. 5Bb), which does not imply that they do not travel across pastures, agricultural, or urban zones, but indicates a higher permanence in areas with forest cover. Oilbirds were detected in places with all possible degrees of fragmentation, but showed a peak at relatively low fragmentation scores (Fig. 5Bc). Several of the frequently used areas were located within transformed matrices, including coffee plantations and visits to isolated trees in pastures. Based on this information, we could suggest that the current degree of fragmentation is not a determining factor in the distribution and landscape use by the Oilbirds.

\section{Influence of the vegetation}

When controlling for the number of plant individuals, the proportion of basal area (BA) of plants consumed by Oilbirds was higher in frequently used areas. When examining the index of species per stem, no differences in diversity were found between plots in frequently used areas and control plots $\left(\mathrm{F}_{1,69}=0.11, \mathrm{P}=\right.$ $0.74)$. On the other hand, the proportion of individuals that were included in the Oilbirds' diet was higher in the frequently visited plots $\left(\mathrm{F}_{1,69}=9.8, \mathrm{P}=0.002\right.$; Fig. $\left.6 \mathrm{a}\right)$, as well as the proportion of BA of consumed plant species $\left(F_{1,69}=4.23, P=0.04\right.$; Fig. $\left.6 b\right)$. Moreover, to evaluate if this difference was due to the presence of particular forest types, the same comparison was made removing plots from forests that do not have many elements consumed by the Oilbirds, such as those dominated by species of white oak (Quercus humboldtii), black oak (Trigonobalanus excelsa), and Alfaroa colombiana. These species are not part of 
Fig. 5. Ecological-niche factor analysis (ENFA) for Oilbirds in the southern Andes of Colombia: (A) Biplot of ENFA, where the $\mathrm{x}$-axis represents marginality and the $y$-axis represents specialization. The length of vectors shows the contribution of the variable and its influence in the position of the ecological niche (dark gray) relative to the available habitat (light gray). (B) Histograms for three variables in the ENFA, in which the habitat available in the area used by Oilbirds is shown in white, and gray events of presence obtained through GPS tags.

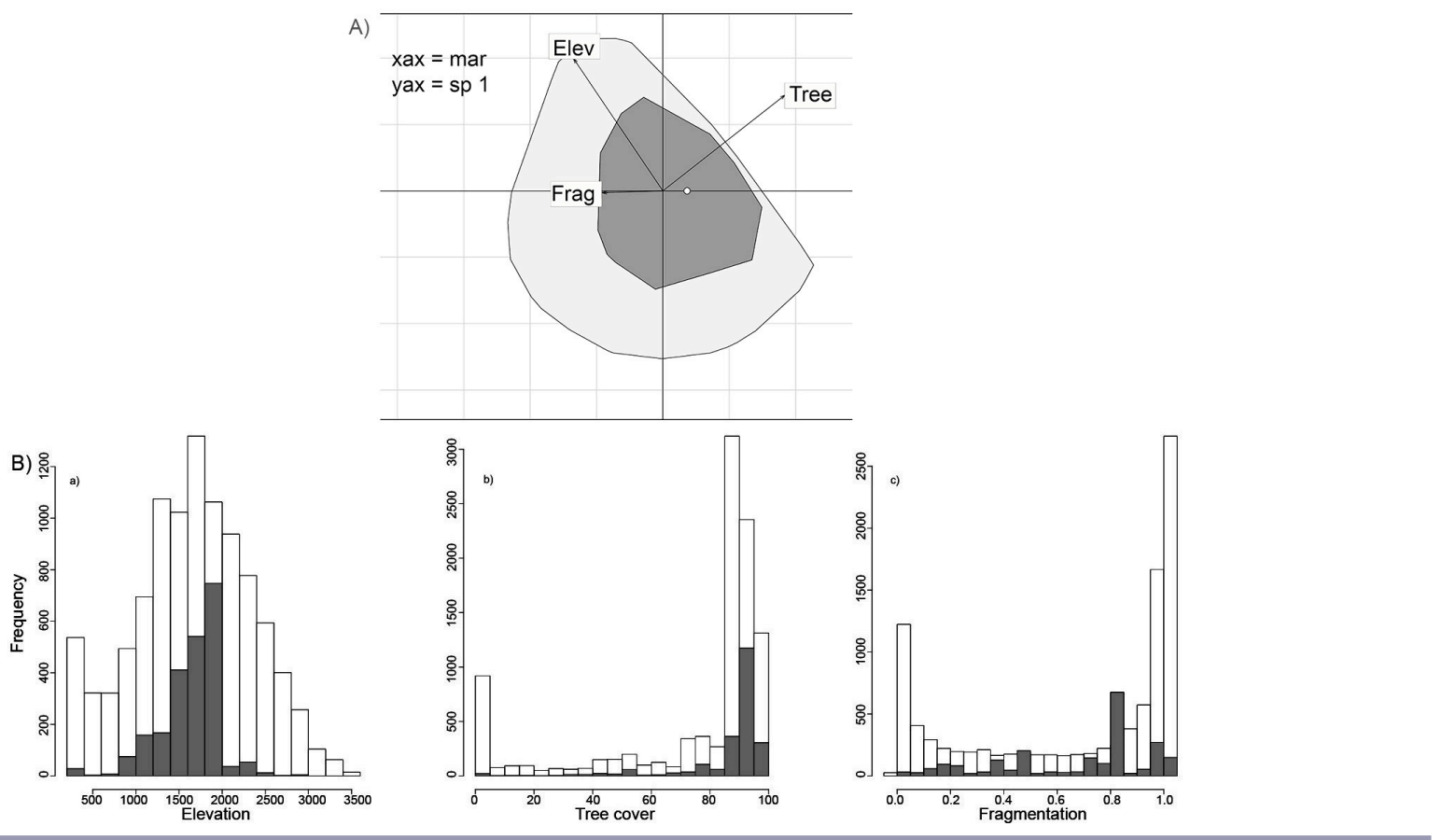

the Oilbirds' diet and in 6 control plots represented between 60 and $90 \%$ of the total BA, which when removed from the analyses, the difference in the proportion of $\mathrm{BA}$ of consumed individuals was no longer significant $\left(\mathrm{F}_{1,63}=2.35, \mathrm{df}=63, \mathrm{P}=0.13\right)$. This suggests the avoidance of this highly dominated type of forest by Oilbirds because none of the frequently used plots presented dominance of these plants.

Fig. 6. Comparison between (a) the proportion of trees and palms that may be consumed by Oilbirds and (b) the proportion of basal area (BA) of those plants, in plots frequently used by Oilbirds fitted with GPS tags, and plots in which they have not been reported, established in the departments of Huila and Caquetá.
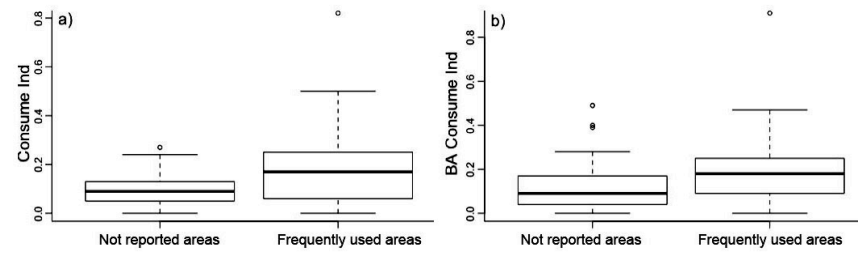

\section{DISCUSSION}

Results show long travel distances and large home ranges for Oilbirds in the PNN Cueva de Los Guacharos, showing larger estimates than most continental Neotropical birds (Appendix 2, Table A2.1). From a review of resident neotropical birds, the largest home ranges studied occur in raptors and scavengers, such as eagles and condors. Among frugivorous, those with more extensive ranges are parrots, which are considered fruit predators. In previous studies, it was reported that Oilbirds could fly up to $73.5 \mathrm{~km}$ away from the central cave (Holland et al. 2009), a value similar to the one reported in this study of $58.2 \mathrm{~km}$. Even though the results from this study underestimate home-range values, they suggest that the magnitude of the areas these birds can cover is considerable. For other frugivorous Neotropical species, such as Ramphastos tucanus, R. vitellinus, and Pteroglossus pluricinctus (Ramphastidae), home ranges of $0.8-9.66 \mathrm{~km}^{2}$ (Holbrook 2011) have been estimated, which is about 7 times lower than the values found for Oilbirds in this study. Ceratogymna atrata and Ceratogymna cylindricus (now Bycanistes cylindricus), frugivorous birds, considered to be important seed dispersers in Africa from the Bucerotidae family (Holbrook and Smith 2000, Mueller et al. 2014), have home ranges between $9.25-44.72 \mathrm{~km}^{2}$ (Holbrook and Smith 2000) and traveled distances of up to $15 \mathrm{~km}$ for Bycanistes bucinator (Mueller et al. 2014), which are also lower than the values reported for the Oilbirds.

Another interesting fact is the confirmation that these birds can spend several days outside the cave, as has been previously reported in Venezuela (Holland et al. 2009). Given their broad home range, they may play an important role as long-distance seed dispersers, even more so when they do not return to the cave 
every night. If this is so, Oilbirds would be dispersing seeds far from their parent trees, allowing them to escape possible pathogens, to avoid competition, and to colonize new habitats, thus giving them an advantage for establishment (Howe and Smallwood 1982, Kellner and Hubbell 2018).

Considering the low number of Oilbirds providing data from GPS devices, it is difficult to infer definitive conclusions. However, the results suggest that movement patterns might differ between breeding and nonbreeding seasons. During the reproductive season, birds showed higher flight speeds, longer daily traveled distances, and more extensive home ranges compared to the individual monitored outside the reproductive season. At the same time, they spent a lower proportion of days outside the cave, compared to the individual monitored in the nonbreeding season. This could be related to the fact that during the reproductive season birds are forced to return to their nests in the cave to take care of the chicks, whereas outside the reproductive season, birds can spend several days outside the cave near foraging sites, as reported by Holland and collaborators (2009). This would also explain patterns of high flight speeds at the beginning of the night, when they leave the cave, and early in the morning when they must return to the cave, especially during the breeding period. The median overall speed was low, probably because Oilbirds tend to forage for fruits in flight, and these foraging movements require low velocity.

Our results indicate that caves were the most frequently used habitat, which is vital to complete reproductive cycles, and habitats with high tree cover were the second most important, allowing Oilbirds to find feeding sources. However, high levels of fragmentation did not seem to limit their movements because they could overfly above crop and pasture matrices, using the whole range of fragmentation scores in the matrix studied. It is known that for several bird species, long distances between desired covers (such as forests), mountains, rivers, roads, and even behavioral limitations can restrict their movement (Bélisle and St. Clair 2002, Harris and Reed 2002, Laurance et al. 2004). For the Oilbirds we tracked, long distances were traveled both over continuous forest cover, and over severely fragmented areas (at least $10 \mathrm{~km}$ flying over pastures), suggesting that they may not require stepping stones to cover long distances. Long-wattled Umbrellabirds (Cephalopterus penduliger) can fly over open zones in Ecuador, allowing seed dispersal and gene flow between plant populations of different forest fragments (Karubian et al. 2012b). Oilbirds could be playing similar roles in their distribution range, even at broader spatial scales, and generating opportunities for plants to colonize new habitats, taking seeds to isolated places. Even though they were detected mainly in areas with high forest cover, they also forage in pastures and crops, in which they may find fruit sources (for instance, Nectandra acutifolia was found in open habitats). It is not clear how they know where these fruit trees are located, but their relatively unidirectional and nonerratic movement patterns suggest a previous knowledge of their location. This could be explained by mental maps and/or the sharing of information among colony members, which could be a topic for future studies.

At the scale of plots, it was evident that feeding trees are associated with the habitat-use frequency. The number, proportion, and basal area of consumed species were higher in the frequently used areas than in control plots (Appendix 1, Fig. A1.1), showing a prevalent role of fruit productivity rather than diversity. The diet of Oilbirds includes species with high contents of lipids such as laurels and some palms (Stevenson et al. 2017) and the sites that they visit present an abundance of consumed species. We also evidenced that frequently used sites had a high density of feeding trees, and within the study area, $58 \%$ of the frequently used plots had at least one large individual of consumed species (which possibly determined use). However, these species are also present in some control plots that might also be visited by the Oilbirds. A more considerable sampling effort would be required to confirm that Oilbirds would visit control sites when these species are fruiting. The analysis of vegetation differences between frequently used and control plots showed that when plots placed in oak forests were excluded (dominated by Trigonobalanus excelsa, Quercus humboldtii from the Fagaceae family and Alfaroa colombiana from the Juglandaceae family), differences were not significant. This suggests that Oilbirds avoid these zones in which there are fewer food resources for them.

Given the large home-range size found, the conservation of this colony very likely depends on the protection of forests in the whole region. Fortunately, in this region of Colombia, there is a network of national (Cueva de Los Guacharos, Churumbelos, Alto Fragua-Indi Wasi, and Puracé) and regional natural parks (e.g., Corredor Oilbirds in Puracé) that favor the maintenance of forest ecosystems. However, it was estimated that only $39.5 \%$ of the original cover remained by 2000 in the Andean territory of Colombia (Rodríguez et al. 2006) and annual deforestation in a recent year was 26,014 ha (Galindo et al. 2014). Although Oilbirds can tolerate open zones because of their wide home ranges, it is necessary to know which fragmentation threshold sustains appropriate resources and how far they can travel between forest patches. To overcome this and given the reports of individuals of this species using isolated trees, we suggest that the maintenance of forest cover in other landscape elements is necessary (as long as they include trees of the species consumed by the Oilbirds). It is also important to outline that not all types of forest cover are adequate for the species because commonly occurring vegetation types in the study area such as oak forests, and the forested plantations do not offer many resources.

Our results indicate that the elevation is also a variable that restricts habitat use by the Oilbirds, keeping their activities within an altitudinal range of 200-3000 masl, but with a higher frequency between 1000-2000 masl. Avoiding high elevations is likely a product of the fact that in this region at high altitudes, there is a preponderance of oak forests (Prada and Stevenson 2016). Besides, most flight paths to lowlands in Caquetá went through a narrow, low altitude area in the edge of the Eastern Cordillera, which could be associated with a preference for routes that minimize climbs and maintain relatively straight movements.

\section{CONCLUSION}

Landscape composition such as cover types, elevation, and plant composition play significant roles in habitat selection and movement patterns in Oilbirds. Oilbirds use caves very frequently, nesting in conditions that may minimize predation rates, and they prefer forest cover, in which they visit a particular set of fruiting plants. Our findings show that they move widely, visiting distant fragments or even isolated trees to find feeding resources in areas 
of at least $4517 \mathrm{~km}^{2}$, avoiding high elevation areas, where their preferred food plants are scarce. Although Oilbirds are capable of inhabiting fragmented landscapes, our results highlight the importance of forests to maintain their nutritional needs. Because they use different habitats such as plantations, crops, and grass mosaics (as long as they have available resources), it is essential to maintain their feeding trees in the landscape to assure Oilbirds' visits, and thus, their ecosystem services.

Responses to this article can be read online at: http://www.ace-eco.org/issues/responses.php/1564

\begin{abstract}
Acknowledgments:
We thank the researchers who established plots of vegetation and who helped determine the botanical specimens: Manuel Lequerica, Laura Molina, and María Paula Kairuz. We also thank Santiago Palacios for his logistical support in this phase. Sebastian GonzálezCaro helped us suggesting data analyses. We also thank Luis Miguel Renjifo and Juan Benavides for their comments and Dr. Alex Jahn and an anonymous reviewer for the useful comments on the manuscript. Finally, we thank Facultad de Estudios Ambientales y Rurales (Pontificia Universidad Javeriana) for allowing us to use GIS and habitat cover maps. This project was funded by Amazon Conservation Team Colombia and the Universidad de Los Andes (Viderectoría de Investigaciones).
\end{abstract}

\section{LITERATURE CITED}

Amatulli, G., S. Domisch, M.-N. Tuanmu, B. Parmentier, A. Ranipeta, J. Malczyk, and W. Jetz. 2018. A suite of global, crossscale topographic variables for environmental and biodiversity modeling. Scientific Data 5:180040. https://doi.org/10.1038/ sdata. 2018.40

Amico, G. C., and M. A. Aizen. 2005. Dispersión de semillas por aves en un bosque templado de Sudamérica austral: ¿quién dispersa a quién? Ecología Austral 15(1):89-100. [online] URL: https://bibliotecadigital.exactas.uba.ar/download/ecologiaaustral/ ecologiaaustral_v015_n01_p089.pdf

Andrén, H. 1994. Effects of habitat fragmentation on birds and mammals in landscapes with different proportions of suitable habitat: a review. Oikos 71:355-366. https://doi.org/10.2307/3545823

Bélisle, M., and C. C. St. Clair. 2002. Cumulative effects of barriers on the movements of forest birds. Conservation Ecology 5(2):9. https://doi.org/10.5751/ES-00312-050209

Bivand, R., T. Keitt, and B. Rowlingson. 2016. rgdal: bindings for the 'geospatial' data abstraction library. Version 1.3-6. R Package. R Foundation for Statistical Computing, Vienna, Austria. [online] URL: https://cloud.r-project.org/web/packages/rgdal/index.html

Bosque, C. 2002. Steatornithidae: Oilbirds. Pages 373-376 in B. Grzimek, editor. Grzimek's animal life encyclopaedia, vol. 2. Gale group, Farmington Hills, Michigan, USA.

Bosque, C., and O. de Parra. 1992. Digestive efficiency and rate of food passage in Oilbird nestlings. Condor 94:557-571. https:// doi.org/10.2307/1369240
Bosque, C., R. Ramírez, and D. Rodríguez. 1995. The diet of the Oilbird in Venezuela. Ornitologia Neotropical 6:67-80. [online] URL: http://www.ibiologia.unam.mx/pdf/links/neo/rev6/vol6_2/ ornitol_6_2_67-80.pdf

Calenge, C. 2006. The package adehabitat for the R software: a tool for the analysis of space and habitat use by animals. Ecological Modelling 197:516-519 https://doi.org/10.1016/j. ecolmodel.2006.03.017

Calenge, C. 2011. Home range estimation in $R$ : the adehabitat $H R$ package. Office national de la chasse et de la faune sauvage, Saint Benoist, Auffargis, France. [online] URL: https://www. rdocumentation.org/packages/adehabitatHR/versions/0.4.18

Díaz Vélez, M. C., W. R. Silva, M. A. Pizo, and L. Galetto. 2015. Movement patterns of frugivorous birds promote functional connectivity among Chaco Serrano woodland fragments in Argentina. Biotropica 47(4):475-483. https://doi.org/10.1111/ btp. 12233

Dutilleul, P., P. Clifford, S. Richardson, and D. Hemon. 1993. Modifying the $t$ test for assessing the correlation between two spatial processes. Biometrics 49:305-314. https://doi.org/10.2307/2532625

Fahrig, L. 2007. Non-optimal animal movement in humanaltered landscapes. Functional Ecology 21(6):1003-1015. https:// doi.org/10.1111/j.1365-2435.2007.01326.x

Frair, J. L., E. H. Merrill, D. R. Visscher, D. Fortin, H. L. Beyer, and J. M. Morales. 2005. Scales of movement by elk (Cervus elaphus) in response to heterogeneity in forage resources and predation risk. Landscape Ecology 20(3):273-287. https://doi. org/10.1007/s10980-005-2075-8

Fritz, H., S. Said, and H. Weimerskirch. 2003. Scale-dependent hierarchical adjustments of movement patterns in a long-range foraging seabird. Proceedings of the Royal Society of London. Series B: Biological Sciences 270(1520):1143-1148. https://doi. org/10.1098/rspb.2003.2350

Galindo, G., O. J. Espejo, J. P. Ramírez, C. Forero, C. A. Valbuena, J. C. Rubiano, R. H. Lozano, K. M. Vargas, A. Palacios, S. Palacios, C. A. Franco, E. I. Granados, L. K. Vergara, and E. Cabrera. 2014. Memoria técnica de la cuantificación de la superficie de bosque natural y deforestación a nivel nacional. Actualización periodo 2012-2013. Instituto de Hidrología, Meteorología y Estudios Ambientales, Bogotá D.C., Colombia.

Gill, R. E., T. L. Tibbitts, D. C. Douglas, C. M. Handel, D. M. Mulcahy, J. C. Gottschalck, N. Warnock, B. J. McCaffery, P. F. Battley, and T. Piersma. 2008. Extreme endurance flights by landbirds crossing the Pacific Ocean: ecological corridor rather than barrier? Proceedings of the Royal Society of London B: Biological Sciences. 276(1656):447-457. https://doi.org/10.1098/ rspb.2008.1142

Gillies, C. S., and C. C. St. Clair. 2010. Functional responses in habitat selection by tropical birds moving through fragmented forest. Journal of Applied Ecology 47(1):182-190. https://doi. org/10.1111/j.1365-2664.2009.01756.x

Gobeil, J.-F., and M. A. Villard. 2002. Permeability of three boreal forest landscape types to bird movements as determined from experimental translocations. Oikos 98(3):447-458. https://doi. org/10.1034/j.1600-0706.2002.980309.x 
González-Caro, S., and Á. Vásquez. 2017. Estado de los bosques de Antioquia entre 1990-2015. Pages 63-80 in E. Quintero Vallejo, A. M. Benavides, N. Moreno, and S. González-Caro, editors. Bosques Andinos: estado actual y retos para su conservación en Antioquia. Fundaci $\tilde{A}^{3} n$ Jardín Botánico de Medellín Joaquín Antonio Uribe, Programa Bosques Andinos, Medellín, Columbia.

Gosper, C. R., C. D. Stansbury, and G. Vivian-Smith. 2005. Seed dispersal of fleshy-fruited invasive plants by birds: contributing factors and management options. Diversity and Distributions 11 (6):549-558. https://doi.org/10.1111/j.1366-9516.2005.00195.x

Hansen, M. C., P. V. Potapov, R. Moore, M. Hancher, S. A. Turubanova, A. Tyukavina, S. Thau. S. V. Stehman, S. J. Goetz, T. R. Loveland, A. Kommareddy, A. Egorov, L. Chini, C. O. Justice, and J. R. G. Townshend. 2013. High-resolution global maps of 21st-century forest cover change. Science 342 (6160):850-853. https://doi.org/10.1126/science.1244693

Harris, R. J., and J. M. Reed. 2002. Behavioral barriers to nonmigratory movements of birds. Annales Zoologici Fennici 39:275-290.

Hayes, F. E., and J.-A. N. Sewlal. 2004. The Amazon River as a dispersal barrier to passerine birds: effects of river width, habitat and taxonomy. Journal of Biogeography 31(11):1809-1818. https:// doi.org/10.1111/j.1365-2699.2004.01139.x

Herrmann, J. D., T. A. Carlo, L. A. Brudvig, E. I. Damschen, N. M. Haddad, D. J. Levey, J. L. Orrock, and J. J. Tewksbury. 2016. Connectivity from a different perspective: comparing seed dispersal kernels in connected vs. unfragmented landscapes. Ecology 97(5):1274-1282. https://doi.org/10.1890/15-0734.1

Hijmans, R. J., and J. van Etten. 2014. raster: Geographic data analysis and modeling. $\mathrm{R}$ package version 2(8). R Foundation for Statistical Computing, Vienna, Austria. [online] URL: https:// CRAN.R-project.org/package=raster

Hirzel, A. H., J. Hausser, D. Chessel, and N. Perrin. 2002. Ecological-niche factor analysis: how to compute habitatsuitability maps without absence data?. Ecology 83(7):2027-2036. https://doi.org/10.1890/0012-9658(2002)083[2027:ENFAHT]2.0. $\mathrm{CO} ; 2$

Hobbs, R. J., and C. J. Yates. 2003. Impacts of ecosystem fragmentation on plant populations: generalising the idiosyncratic. Australian Journal of Botany 51(5):471-488. https:// doi.org/10.1071/bt03037

Holbrook, K. M. 2011. Home range and movement patterns of toucans: implications for seed dispersal. Biotropica 43(3):357-364. https://doi.org/10.1111/j.1744-7429.2010.00710.x

Holbrook, K. M., and T. B. Smith. 2000. Seed dispersal and movement patterns in two species of Ceratogymna hornbills in a West African tropical lowland forest. Oecologia 125(2):249-257. https://doi.org/10.1007/s004420000445

Holland, R. A., M. Wikelski, F. Kümmeth, and C. Bosque. 2009. The secret life of Oilbirds: new insights into the movement ecology of a unique avian frugivore. PLoS one 4(12):1-6. https://doi. org/10.1371/journal.pone.0008264
Howe, H. F., and J. Smallwood. 1982. Ecology of seed dispersal. Annual Review of Ecology and Systematics 13:201-228. https:// doi.org/10.1146/annurev.es.13.110182.001221

Hubbell, S. P., R. B. Foster, S. T. O'Brien, K. E. Harms, R. Condit, B. Wechsler, S. J. Wright, and S. Loo de Lao. 1999. Light-gap disturbances, recruitment limitation, and tree diversity in a neotropical forest. Science 283(5401):554-557. https://doi. org/10.1126/science.283.5401.554

Johnson, C. J., K. L. Parker, D. C. Heard, and M. P. Gillingham. 2002. Movement parameters of ungulates and scale-pecific responses to the environment. Journal of Animal Ecology 71 (2):225-235. https://doi.org/10.1046/j.1365-2656.2002.00595.X

Karubian, J., L. Browne, C. Bosque, T. Carlo, M. Galetti, B. A. Loiselle, J. G. Blake, D. Cabrera, R. Durães, F. M. Labecca, K. M. Holbrook, R. Holland, W. Jetz, F. Kümmeth, J. Olivo, K. Ottewell, G. Papadakids, G. Rivas, S. Steiger, B. Voirin, and M. Wikelski. 2012a. Seed dispersal by neotropical birds: emerging patterns and underlying processes. Ornitologia Neotropical 23:9-24. [online] URL: https://sora.unm.edu/sites/default/files/ Karubian.pdf

Karubian, J., R. Duraes, J. L. Storey, and T. B. Smith. $2012 b$. Mating behavior drives seed dispersal by the long-wattled umbrellabird Cephalopterus penduliger. Biotropica 44(5):689-698. https://doi.org/10.1111/j.1744-7429.2012.00859.x

Kellner, J. R., and S. P. Hubbell. 2018. Density-dependent adult recruitment in a low-density tropical tree. Proceedings of the National Academy of Sciences 115(44):11268-11273. https://doi. org/10.1073/pnas.1800353115

Laurance, S. G. W., P. C. Stouffer, and W. F. Laurance. 2004. Effects of road clearings on movement patterns of understory rainforest birds in central Amazonia. Conservation Biology 18 (4):1099-1109. https://doi.org/10.1111/j.1523-1739.2004.00268.x

Levey, D. J., B. M. Bolker, J. J. Tewksbury, S. Sargent, and N. M. Haddad. 2005. Effects of landscape corridors on seed dispersal by birds. Science 309(5731):146-148. https://doi.org/10.1126/ science. 1111479

Maniguaje, L., A. Duque, D. Cárdenas, and F. Moreno. 2011. Changes in seed dispersal spectrum along the altitudinal gradient between wet Amazonian and Andean forest in Colombia. Colombia Amazónica 4:35-42. [online] URL: https://www.sinchi. org.co/files/publicaciones/revista/pdf $/ 4 / 5 \% 20$ changes $\% 20 \mathrm{in} \% 20$ seed $\%$ 20dispersal $\% 20$ spectrum $\% 20$ along $\% 20$ the $\% 20$ altitutdinal $\% 20$ gradiet $\%$ 20 wet $\% 20$ amazonian $\% 20$ and $\% 20$ andean $\% 20$ forests $\% 20$ in $\% 20$ colombia. pdf

Ministerio de Ambiente Vivienda y Desarrollo Territorial (MINAMBIENTE). 2005. Plan de manejo 2005-2009. Parque Nacional Natural Cueva de los Guacharos. Ministerio de Ambiente Vivienda y Desarrollo Territorial. Unidad administrativa especial del sistema de Parques Nacionales Naturales, Bogotá, Columbia. [online] URL: https://www.yumpu.com/es/document/read/43374397/ plan-de-manejo-2005-2009-parque-nacional-natural-cueva

Mueller, T., J. Lenz, T. Caprano, W. Fiedler, and K. BöhningGaese. 2014. Large frugivorous birds facilitate functional connectivity of fragmented landscapes. Journal of Applied Ecology 51(3):684-692. https://doi.org/10.1111/1365-2664.12247 
Nathan, R. 2006. Long-distance dispersal of plants. Science 313 (5788):786-788. https://doi.org/10.1126/science.1124975

Neuschulz, E. L., M. Brown, and N. Farwig. 2013. Frequent bird movements across a highly fragmented landscape: the role of species traits and forest matrix. Animal Conservation 16 (2):170-179. https://doi.org/10.1111/j.1469-1795.2012.00582.x

Open Source Geospatial Foundation (OSGEO). 2018. GDAL/ OGR geospatial data abstraction software library. Open Source Geospatial Foundation, Beaverton, Oregon, USA. P[online] URL: http://gdal.org

Pebesma, E., and R. S. Bivand. 2005. Classes and methods for spatial data: the sp package. $R$ News 5(2):9-13.

Prada, C. M., and P. R. Stevenson. 2016. Plant composition associated with environmental gradients in tropical montane forests (Cueva de Los Guacharos National Park, Huila, Colombia). Biotropica 48(5):568-576. https://doi.org/10.1111/ btp. 12331

R Development Core Team. 2012. R: a language and environment for statistical computing. Version 2.14.2. R Foundation for Statistical Computing, Vienna, Austria.

Roca, R. L. 1994. Oilbirds of Venezuela: ecology and conservation. Publications of the Nuttall Ornithological Club. Cambridge, Massachusetts, USA.

Rodríguez, N., D. Armenteras, M. Morales, and M. Romero. 2006. Ecosistemas de los Andes Colombianos. Segunda edición. Instituto de Investigación de Recursos Biológicos Alexander von Humboldt, Bogotá, Colombia.

Rojas-Lizarazo, G. 2016. Dieta y reproducción en una colonia de guácharos (Steatornis caripensis) de alta montaña en Colombia. Ornitología Colombiana (15).

Roshier, D. A., and M. W. Asmus. 2009. Use of satellite telemetry on small-bodied waterfowl in Australia. Marine and Freshwater Research 60(4):299-305. https://doi.org/10.1071/MF08152

Scharf, H. R., M. B. Hooten, R. R. Wilson, G. M. Durner, and T. C. Atwood. 2018. Accounting for phenology in the analysis of animal movement. Biometrics 75:810-820. https://doi.org/10.1111/ biom.13052

Snow, D. W. 1961. The natural history of the Oilbird, Steatornis caripensis, in Trinidad, WI. New York Zoological Society, New York, New York, USA.

Stevenson, P. R., L. M. Cardona, D. C. Acosta-Rojas, F. Henao Díaz, and S. Cárdenas. 2017. Diet of Oilbirds (Steatornis caripensis) in Cueva de los Guácharos National Park (Colombia): temporal variation in fruit consumption, dispersal, and seed morphology. Ornitología Neotropical 28:295-307. [online] URL: http://journals.sfu.ca/ornneo/index.php/ornneo/article/view/243/ ON $\% 2028 \% 20 \% 282017 \% 29 \% 20295-307$.pdf
Stevenson, P. R., and D. C. Guzmán-Caro. 2010. Nutrient transport within and between habitats through seed dispersal processes by woolly monkeys in north-western Amazonia. American Journal of Primatology 72(11):992-1003. https://doi. org/10.1002/ajp.20852

Symes, C. T., and S. J. Marsden. 2007. Patterns of supra-canopy flight by pigeons and parrots at a hill-forest site in Papua New Guinea. Emu -Austral Ornithology 107(2):115-125. https://doi. org/10.1071/MU06041

Tannenbaum B., and P. Wrege. 1978. Ecology of the guacharo (Steatornis caripensis) in Venezuela. Boletín de la Academia de Ciencias Físicas, Matemáticas y Naturales 38:83-90

Tello, N. S., M. Stojan-Dolar, and E. W. Heymann. 2008. A sight and video record of the Oilbird, Steatornis caripensis, in Peruvian lowland Amazonia. Journal of Ornithology 149:267-269 https:// doi.org/10.1007/s10336-007-0266-6

Thomas, B. T. 1999. Family Steatornithidae (Oilbird). Pages 244-250 in J. Del Hoyo, E. Elliott, and J. Sargatal, editors. Handbook of the birds of the world. Volume 5. Lynx Ediciones, Barcelona, Spain.

Villard, M.-A., M. K. Trzcinski, and G. Merriam. 1999. Fragmentation effects on forest birds: relative influence of woodland cover and configuration on landscape occupancy. Conservation Biology 13(4):774-783. https://doi.org/10.1046/ j.1523-1739.1999.98059.x
Editor-in-Chief: Keith A.Hobson Subject Editor: Nicholas JBayly
Sponsored by the Society of Canadian Ornithologists and Birds Canada

Parrainée par la Société des ornithologistes du Canada et Oiseaux Canada

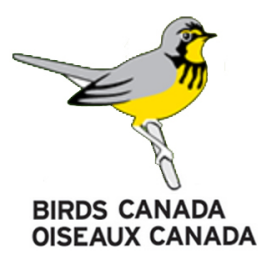


Appendix 1. Field data.

Table A1.1. Number of individuals, species richness, diversity (ind./spp), consumed plant individuals and their proportion (Ind. Prop.), total basal area (BA) of consumed species, and their proportion (Prop. AB) within vegetation plots. Plots beginning with Pufe. correspond to frequently used areas, and the other ones represent other places in Huila and Caquetá.

\begin{tabular}{|c|c|c|c|c|c|c|c|c|c|}
\hline Plot & \# trees & Species & Ind/spp & $\begin{array}{l}\text { Consumed } \\
\text { individuals }\end{array}$ & $\begin{array}{l}\text { Prop. } \\
\text { Ind. }\end{array}$ & $\begin{array}{c}\text { BA } \\
\text { Consum } \\
\end{array}$ & $\begin{array}{c}\text { Total } \\
\text { BA } \\
\end{array}$ & $\begin{array}{c}\text { Prop. } \\
\text { BA }\end{array}$ & Control \\
\hline A1 - 900 & 83 & 57 & 1.46 & 7 & 0.08 & 1571 & 50320 & 0.03 & 1 \\
\hline A2 -1100 & 92 & 66 & 1.39 & 11 & 0.12 & 10818 & 62956 & 0.17 & 1 \\
\hline A3 -1300 & 75 & 49 & 1.53 & 8 & 0.11 & 2772 & 64032 & 0.04 & 1 \\
\hline A4 - 1500 & 151 & 46 & 3.28 & 10 & 0.07 & 1827 & 39704 & 0.05 & 1 \\
\hline GR1 & 116 & 46 & 2.52 & 10 & 0.10 & 3836 & 49228 & 0.10 & 1 \\
\hline GR2 & 57 & 24 & 2.38 & 2 & 0.19 & 460 & 22533 & 0.19 & 1 \\
\hline GT1 & 61 & 22 & 2.77 & 5 & 0.21 & 3268 & 32273 & 0.22 & 1 \\
\hline GT2 & 150 & 35 & 4.29 & 12 & 0.12 & 8180 & 79665 & 0.13 & 1 \\
\hline GUAC1 & 84 & 33 & 2.55 & 18 & 0.21 & 3681 & 35609 & 0.10 & 1 \\
\hline GUAC10 & 97 & 30 & 3.23 & 13 & 0.13 & 10812 & 52425 & 0.21 & 1 \\
\hline GUAC11 & 95 & 40 & 2.38 & 17 & 0.18 & 5922 & 61621 & 0.10 & 1 \\
\hline GUAC12 & 104 & 47 & 2.21 & 24 & 0.23 & 5082 & 42423 & 0.12 & 1 \\
\hline GUAC13 & 100 & 42 & 2.38 & 7 & 0.07 & 1923 & 25015 & 0.08 & 1 \\
\hline GUAC14 & 106 & 29 & 3.66 & 20 & 0.19 & 14035 & 36087 & 0.39 & 1 \\
\hline GUAC15 & 83 & 34 & 2.44 & 17 & 0.20 & 8933 & 37742 & 0.24 & 1 \\
\hline GUAC16 & 108 & 34 & 3.18 & 5 & 0.05 & 1349 & 30690 & 0.04 & 1 \\
\hline GUAC17 & 104 & 44 & 2.36 & 14 & 0.13 & 1648 & 25257 & 0.07 & 1 \\
\hline GUAC18 & 78 & 42 & 1.86 & 10 & 0.13 & 1861 & 28891 & 0.06 & 1 \\
\hline GUAC19 & 74 & 6 & 12.33 & 1 & 0.01 & 104 & 75751 & 0.00 & 1 \\
\hline GUAC2 & 281 & 53 & 5.30 & 75 & 0.27 & 7838 & 35526 & 0.22 & 1 \\
\hline GUAC20 & 64 & 19 & 3.37 & 1 & 0.02 & 115 & 11706 & 0.01 & 1 \\
\hline GUAC3 & 85 & 12 & 7.08 & 2 & 0.02 & 342 & 73096 & 0.00 & 1 \\
\hline GUAC4 & 99 & 33 & 3.00 & 11 & 0.11 & 4579 & 37298 & 0.12 & 1 \\
\hline GUAC5 & 88 & 37 & 2.38 & 12 & 0.14 & 3669 & 55948 & 0.07 & 1 \\
\hline GUAC6 & 91 & 40 & 2.28 & 12 & 0.13 & 4662 & 38181 & 0.12 & 1 \\
\hline GUAC7 & 98 & 21 & 4.67 & 9 & 0.09 & 1121 & 34585 & 0.03 & 1 \\
\hline GUAC8 & 130 & 49 & 2.65 & 12 & 0.09 & 2579 & 37667 & 0.07 & 1 \\
\hline GUAC9 & 92 & 32 & 2.88 & 5 & 0.05 & 1182 & 37266 & 0.03 & 1 \\
\hline $\mathrm{P} 1$ & 35 & 21 & 1.67 & 3 & 0.29 & 1234 & 7803 & 0.49 & 1 \\
\hline
\end{tabular}




\begin{tabular}{|c|c|c|c|c|c|c|c|c|}
\hline P2 & 49 & 9 & 5.44 & 4 & 0.37 & 1169 & 26829 & 0.40 \\
\hline PJ1 & 71 & 35 & 2.03 & 7 & 0.15 & 2561 & 37604 & 0.11 \\
\hline PJ2 & 44 & 16 & 2.75 & 2 & 0.24 & 1220 & 15574 & 0.26 \\
\hline $1^{\circ} 1$ Penc & 100 & 44 & 2.27 & 24 & 0.24 & 11402 & 48614 & 0.23 \\
\hline $1^{\circ} 2$ Penc & 81 & 22 & 3.68 & 7 & 0.09 & 2231 & 36992 & 0.06 \\
\hline PUFE092 & 72 & 56 & 1.29 & 12 & 0.17 & 13927 & 44987 & 0.31 \\
\hline PUFE126 & 8 & 3 & 2.67 & 1 & 0.13 & 94 & 2697 & 0.03 \\
\hline PUFE140 & 17 & 6 & 2.83 & 1 & 0.06 & 1645 & 13332 & 0.12 \\
\hline PUFE154 & 81 & 29 & 2.79 & 21 & 0.26 & 4264 & 22905 & 0.19 \\
\hline PUFE160 & 47 & 19 & 2.47 & 13 & 0.28 & 6104 & 33691 & 0.18 \\
\hline PUFE173 & 74 & 28 & 2.64 & 18 & 0.24 & 7213 & 29084 & 0.25 \\
\hline PUFE186 & 85 & 29 & 2.93 & 18 & 0.21 & 5104 & 38272 & 0.13 \\
\hline PUFE276 & 16 & 4 & 4.00 & 1 & 0.06 & 849 & 4676 & 0.18 \\
\hline PUFE279 & 32 & 13 & 2.46 & 1 & 0.03 & 2370 & 29465 & 0.08 \\
\hline PUFE311 & 84 & 29 & 2.90 & 8 & 0.10 & 2707 & 30598 & 0.09 \\
\hline PUFE329 & 40 & 15 & 2.67 & 1 & 0.03 & 207 & 16689 & 0.01 \\
\hline PUFE347 & 10 & 8 & 1.25 & 1 & 0.10 & 608 & 2860 & 0.21 \\
\hline PUFE562 & 54 & 17 & 3.18 & 13 & 0.24 & 5302 & 23566 & 0.22 \\
\hline PUFE579 & 28 & 4 & 7.00 & 23 & 0.82 & 56636 & 62522 & 0.91 \\
\hline PUFE597 & 84 & 26 & 3.23 & 34 & 0.40 & 10056 & 40928 & 0.25 \\
\hline PUFE728 & 16 & 10 & 1.60 & 4 & 0.25 & 2069 & 7460 & 0.28 \\
\hline PUFE780 & 46 & 30 & 1.53 & 8 & 0.17 & 2744 & 21371 & 0.13 \\
\hline PUFE79 & 61 & 15 & 4.07 & 1 & 0.02 & 46 & 21200 & 0.00 \\
\hline PUFE81 & 31 & 3 & 10.33 & 0 & 0.00 & 0 & 4722 & 0.00 \\
\hline PUFE840 & 15 & 12 & 1.25 & 5 & 0.33 & 3672 & 7804 & 0.47 \\
\hline PUFE842 & 18 & 8 & 2.25 & 0 & 0.00 & 0 & 17434 & 0.00 \\
\hline PUFE9 & 88 & 29 & 3.03 & 16 & 0.18 & 10509 & 115457 & 0.09 \\
\hline PUFE128 & 74 & 58 & 1.28 & 11 & 0.15 & 4491 & 34988 & 0.13 \\
\hline PUFE602 & 40 & 13 & 3.08 & 20 & 0.26 & 5780 & 10545 & 0.37 \\
\hline Q1 -900 & 87 & 50 & 1.74 & 4 & 0.05 & 1692 & 32693 & 0.05 \\
\hline Q2 -1100 & 71 & 49 & 1.45 & 5 & 0.07 & 1044 & 34847 & 0.03 \\
\hline Q3 -1300 & 75 & 37 & 2.03 & 0 & 0.00 & 0 & 52410 & 0.00 \\
\hline Q4 -1500 & 122 & 51 & 2.39 & 8 & 0.07 & 6648 & 43380 & 0.15 \\
\hline R1 & 89 & 27 & 3.30 & 14 & 0.13 & 6682 & 35779 & 0.13 \\
\hline R2 & 49 & 19 & 2.58 & 4 & 0.23 & 836 & 16423 & 0.28 \\
\hline $\mathrm{RC} 1$ & 45 & 20 & 2.25 & 2 & 0.27 & 304 & 32322 & 0.21 \\
\hline $\mathrm{RC} 2$ & 64 & 18 & 3.56 & 7 & 0.21 & 2656 & 27160 & 0.17 \\
\hline
\end{tabular}




\begin{tabular}{lccccccccc} 
Ro1Penc & 101 & 15 & 6.73 & 2 & 0.02 & 296 & 33835 & 0.01 & 1 \\
$2^{\circ} 1$ Penc & 59 & 21 & 2.81 & 3 & 0.05 & 513 & 10493 & 0.05 & 1 \\
$2^{\circ}$ PPenc & 118 & 34 & 3.47 & 13 & 0.11 & 2784 & 48335 & 0.06 & 1 \\
\hline
\end{tabular}

Table A1.2. Daily traveled distances and home range for three Oilbirds fitted with GPS tags captured in the PNN Cueva de Los Guácharos (Huila, Colombia).

\begin{tabular}{lcccc}
\hline \hline & G29 & G32 & G33 & Total \\
\hline Average & 19.0 & 52.0 & 79.1 & $\mathbf{5 4 . 7}$ \\
Standard Deviation & 15.4 & 26.4 & 24.5 & $\mathbf{3 1 . 3}$ \\
Max. Distance/night & 48.2 & 101.3 & 112.4 & $\mathbf{1 1 2 . 4}$ \\
Min. Distance/night & 0.9 & 0.0 & 0.0 & $\mathbf{0 . 0}$ \\
50\% Kernel Home Range $\left(\mathrm{km}^{2}\right)$ & 72.8 & 286.5 & 315.3 & $\mathbf{4 8 1 . 7}$ \\
95\% Kernel Home Range $\left(\mathrm{km}^{2}\right)$ & 469.2 & 1747.0 & 1965.3 & $\mathbf{2 5 6 7 . 9}$ \\
\hline
\end{tabular}

Table A1.3. Mean movement patterns (i.e., overall velocity in $\mathrm{km} / \mathrm{h}$, including foraging movements) recorded for three oilbirds captured in the PNN Cueva de Los Guácharos (Huila, Colombia). We found differences in average speed between individuals ( $\mathrm{KW}$ test: $\mathrm{X}^{2}=16.8, \mathrm{df}=2, \mathrm{P}=0.002$ ). Letters represent similar groups, showing that the oilbird on the non-breeding season had the lowest values.

\begin{tabular}{lcccc}
\hline \hline & $\mathrm{G} 29$ & $\mathrm{G} 32$ & $\mathrm{G} 33$ & Mean \\
\hline Average $(\mathrm{km} / \mathrm{h})$ & $3.5 \mathrm{~b}$ & $10.1 \mathrm{a}$ & $11.6 \mathrm{a}$ & $\mathbf{9 . 2}$ \\
Standard Deviation & 9.5 & 15.3 & 16.0 & $\mathbf{1 4 . 8}$ \\
Max. Speed $(\mathrm{km} / \mathrm{h})$ & 54.9 & 56.3 & 59.7 & $\mathbf{5 7 . 0}$ \\
\hline
\end{tabular}




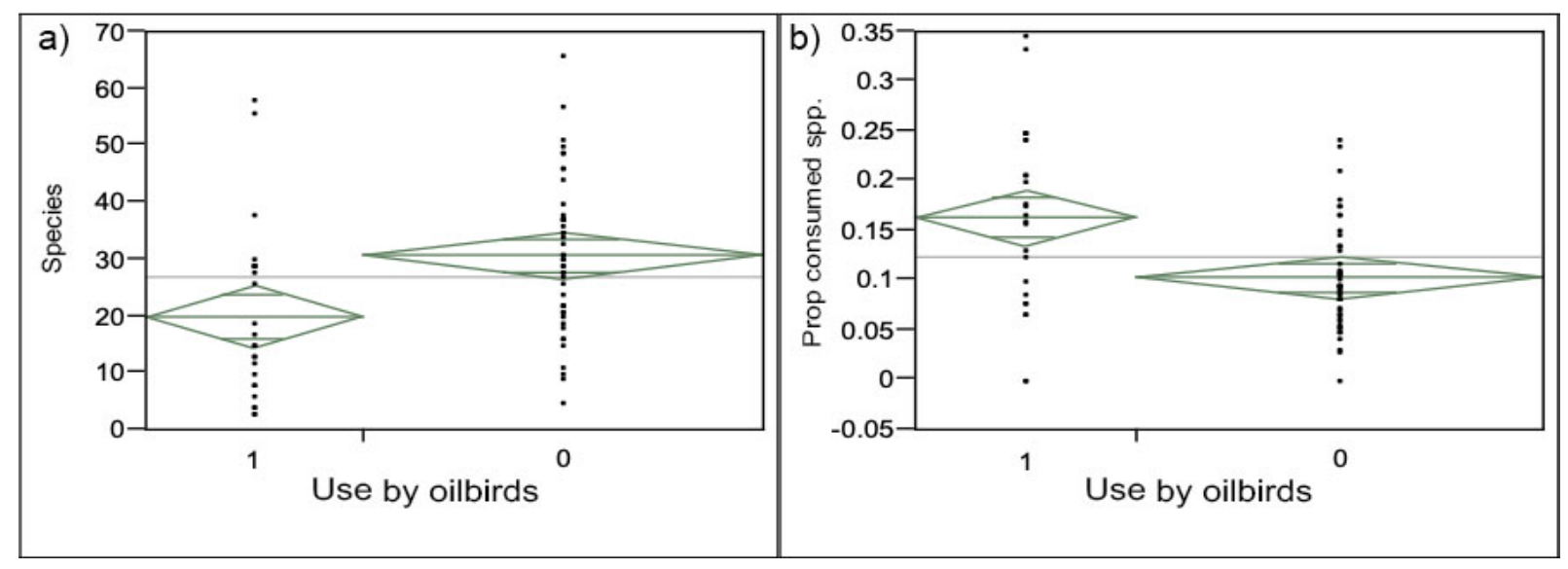

Fig. A1.1. Comparison between (a) plant species richness $\left(\mathrm{F}_{1,64}=14.8, \mathrm{P}=0.0003\right)$ and $(\mathrm{b})$ the proportion of consumed plant species $\left(\mathrm{F}_{1,69}=12.25, \mathrm{P}=0.0008\right)$ in frequented areas $(1)$ and where oilbirds have not been reported (0), in plots established in the Huila and Caquetá departments. 
Appendix 2. Data from a literature search.

Table A2.1. Home range data and daily distances for Neotropical birds. The search was done in google scholar and web of science using the words "neotropical" AND "bird*" AND "home range" AND "daily distance*". Only species from neotropical countries were included. The numbers following species names correspond to the references below the table.

\begin{tabular}{|c|c|c|c|c|}
\hline Species & Common name & Home Range $\left(\mathrm{km}^{2}\right)$ & $\begin{array}{c}\text { Flight path } \\
\text { distance }(\mathrm{km})\end{array}$ & Site \\
\hline Aramides Wolfi ${ }^{18}$ & Brown Wood-Rail & 1350 & & $\begin{array}{l}\text { Bilsa Biological Station, } \\
\text { Ecuador }\end{array}$ \\
\hline Rhynchopsitta terrisi ${ }^{26}$ & $\begin{array}{l}\text { Cotorra serrana } \\
\text { oriental }\end{array}$ & $123.8-47.4$ & $23.62-23.71$ & Sierra Madre Oriental, México \\
\hline Vultur gryphus ${ }^{27}$ & Andean condor & $14.169-66.624$ & & $\begin{array}{l}\text { Andes centrales de Chile y } \\
\text { Argentina }\end{array}$ \\
\hline Crax globulosa ${ }^{20}$ & Wattled Curassow & $8.04 \pm 5.56$ & & $\begin{array}{l}\text { Uacari Sustainable } \\
\text { Development Reserve }\end{array}$ \\
\hline Ara rubrogenys ${ }^{24}$ & Red-fronted Macaw & $3.3-57.38$ & $9-28$ & Andean dry forests, Bolivia \\
\hline Pteroglossus pluricinctus ${ }^{13}$ & Many-banded Araçari & 1.91 & & Yasuní, Ecuador \\
\hline Ramphastos vitellinus ${ }^{13}$ & $\begin{array}{l}\text { Channel-billed } \\
\text { Toucan }\end{array}$ & 0.86 & & Yasuní, Ecuador \\
\hline Ramphastos tucanus ${ }^{13}$ & $\begin{array}{l}\text { White-throated } \\
\text { Toucan }\end{array}$ & 0.86 & & Yasuní, Ecuador \\
\hline
\end{tabular}




\begin{tabular}{|c|c|c|c|c|}
\hline Megascops choliba ${ }^{l}$ & Screech-Owl & $0.808 \pm 0.402$ & & Brazilian Cerrado \\
\hline Tyrannus melancholicus ${ }^{14}$ & Tropical Kingbird & $\begin{array}{l}\text { males }(0.430 \pm 0.226) \text {, } \\
\text { females }(0.456 \pm 0.455)\end{array}$ & & Brazilian Cerrado \\
\hline Nothoprocta ornata ${ }^{9}$ & Ornate Tinamou & $0.438 \pm 0.216$ & & Qurpa \\
\hline Grallaria ridgelyi $^{16}$ & Jocotoco Antpitta & $0.411 \pm 0.053$ & & Reserva Tapichalaca \\
\hline Cyanocorax chrysops ${ }^{37}$ & Plush-crested Jay & $0.2-0.3$ & & Brazil \\
\hline Amazona leucocephala ${ }^{33}$ & Bahama Parrot & $0.186(\mathrm{SE}=19.47)$ & & Great Abaco Island \\
\hline Grallaria varia ${ }^{15}$ & Variegated Antpitta & 0.176 & & Amazonia \\
\hline Colinus cristatus ${ }^{36}$ & Crested bobwhites & $0.161 \pm 0.116$ & $0.360 \pm 0.241$ & $\begin{array}{l}\text { Estación Experimental La } \\
\text { Iguana }\end{array}$ \\
\hline Poospiza cinerea 4 & $\begin{array}{l}\text { Cinereous Warbling- } \\
\text { Finch }\end{array}$ & 0.150 and 0.166 & & Alto da Boa Vista \\
\hline Suiriri affinis ${ }^{22}$ & Campo Suiriri & $0.14 \pm 0.02$ & & Central Brazil \\
\hline Poospiza cinerea ${ }^{23}$ & $\begin{array}{l}\text { Cinereous Warbling- } \\
\text { finch }\end{array}$ & $0.136-0.213$ & & $\begin{array}{l}\text { Paredão da Serra do Curral } \\
\text { City Park }\end{array}$ \\
\hline Suiriri islerorum $^{22}$ & Chapada Flycatcher & $0.112 \pm 0.006$ & & Central Brazil \\
\hline Cipo espinhacensis $^{6}$ & Cipo Cinclodes & 0.093 & & Serra do Breu \\
\hline Sclerurus scansor ${ }^{12}$ & $\begin{array}{l}\text { Rufous-breasted } \\
\text { leaftosser }\end{array}$ & $0.054-0.133$ & $0.059-0.279$ & Atlantic forest \\
\hline Centronyx bairdii ${ }^{32}$ & Baird's sparrow & $0.048 \pm 0.019$ IC $95 \%$ & $\begin{array}{c}0.203 \pm \mathrm{DE} \\
0.187\end{array}$ & Rancho Santa Teresa \\
\hline Ammodramus savannarum $^{32}$ & Grasshopper sparrow & $0.044 \pm 0.023$ IC $95 \%$ & $0.134 \pm$ DE 0.106 & Rancho Santa Teresa \\
\hline Asthenes luizae ${ }^{7}$ & Cipo Canasteros & 0.04 & $\begin{array}{c}1.238,0.780 \text { and } \\
1.056\end{array}$ & Espinhaco Range \\
\hline Mixed flocks ${ }^{17}$ & Mixed flocks & $0.032-0.133$ & & Noragues \\
\hline Parkesia motacilla ${ }^{11}$ & Louisiana Waterthrush & 0.03 & & Caribbean National Forest \\
\hline $\begin{array}{l}\text { Aulacorhynchus } \\
\text { caeruleogularis }^{28}\end{array}$ & $\begin{array}{l}\text { Blue-throated } \\
\text { Toucanet }\end{array}$ & 0.02 & & \\
\hline
\end{tabular}




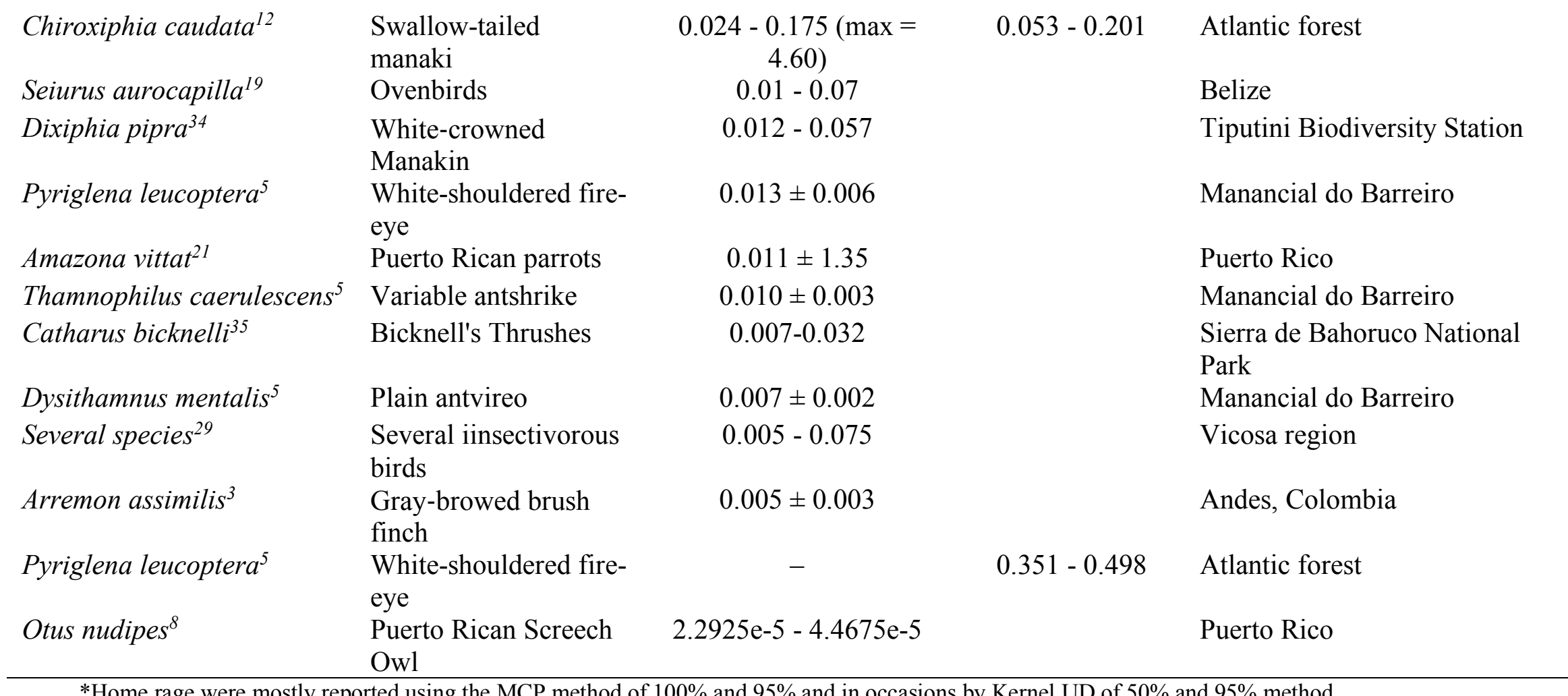

*Home rage were mostly reported using the MCP method of $100 \%$ and $95 \%$ and in occasions by Kernel UD of $50 \%$ and $95 \%$ method 


\section{Literature cited}

1. Barros, F. M., and J. C. Motta-Junior. 2014. Home range and habitat selection by the tropical screech-owl in a Brazilian savanna. Journal of Raptor Research 48(2): 142-151.

2. Bernal, X., and C. A. Mejía. 1995. Uso del espacio por un grupo de Crax alector. Bogotá: Fundación para La Investigación y Tecnologla-Banco de La Republica.

3. Castaño, M. I., C. D. Cadena, and J. E. Avendaño. 2019. Home-range size of an Andean bird: Assessing the role of physical condition. Biotropica 51(4): 591-599.

4. Costa, L. M., and M. Rodrigues. 2013. Notes on Residency, Home Range, and Natural History of the 'Vulnerable'Cinereous Warbling-Finch, Poospiza cinerea. The Wilson Journal of Ornithology 125(2): 433-438.

5. Duca, C., T. J. Guerra, and M. Â. Marini. 2006. Territory size of three Antbirds (Aves, Passeriformes) in an Atlantic Forest fragment in southeastern Brazil. Revista Brasileira de Zoologia 23(3): 692-698.

6. Freitas, G. H., L. M. Costa, P. H. Silva, A. V. Chaves, L. C. Ribeiro, and M. Rodrigues. 2019a. Spatial ecology and conservation of the microendemic ovenbird Cipo Cinclodes (Cinclodes espinhacensis) from the Brazilian highlands. Journal of Field Ornithology 90: 128-142.

7. Freitas, G. H., L. M. Costa, and M. Rodrigues. 2019b. Home-ranges, population densities, vocal behavior, and post-fledging movements of Cipo Canasteros (Asthenes luizae, Furnariidae), a rock-specialist endemic of the highlands of eastern Brazil. Journal of Field Ornithology 90(3): 215-228.

8. Gannon, M., K. Pardieck, M. Willig, \& R. Waide. 1993. Movement and Home Range of the Puerto Rican Screech-Owl (Otus Nudipes) in the Liquillo Experimental Forest. Caribbean Journal Of Science 29(3-4): 174-178.

9. Garitano-Zavala, A., Z. Chura, J. Cotín, X. Ferrer, and J. Nadal. 2013. Home range extension and overlap of the Ornate Tinamou (Nothoprocta ornata) in an Andean agro-ecosystem. The Wilson Journal of Ornithology 125(3): 491-501.

10. Graham, C. 2001. The Condor. Habitat Selection and Activity Budgets of KeelBilled Toucans at the Landscape Level. The Condor 103(4): 776-784.

11. Hallworth, M. T., L. R. Reitsma, and K. Parent. 2011. Habitat use of the Louisiana Waterthrush during the non-breeding season in Puerto Rico. The Wilson Journal of Ornithology 123(3): 567-574.

12. Hansbauer, M. M., I. Storch, Leu, S., J. P. Nieto-Holguin, R. G. Pimentel, F. Knauer, and J. P. W. Metzger. 2008. Movements of neotropical understory passerines affected by anthropogenic forest edges in the Brazilian Atlantic rainforest. Biological Conservation 141(3): 782-791.

13. Holbrook, K. M. 2011. Home range and movement patterns of toucans: implications for seed dispersal. Biotropica 43(3): 357-364. 
14. Jahn, A. E., J. P. Ledezma, A. M. Mamani, L. W. DeGroote, and D. J. Levey. 2010. Seasonal home range size of Tropical Kingbird (Tyrannus melancholicus) in the southern Amazon Basin. Ornitologia Neotropical, 21: 39-46.

15. Jirinec, V., E. C. Elizondo, C. L. Rutt, and P. C. Stouffer. 2018. Space use, diurnal movement, and roosting of a variegated antpitta (Grallaria varia) in central Amazonia. Ornitología Neotropical 29(1): 13-20.

16. Juiña, M., and E. Bonaccorso. 2013. Área de hogar y notas sobre la historia natural de la Gralaria jocotoco (grallaria ridgelyi). Ornitologia neotropical 24: 27-34.

17. Jullien, M., and J. M. Thiollay. 1998. Multi-species territoriality and dynamic of neotropical forest understorey bird flocks. Journal of Animal Ecology 67(2): 227252.

18. Karubian J., L. Carrasco, P. Mena, J. Olivo, D. Cabrera, F. Castillo, R. Durães, and N. El Ksabi. 2011. Nesting Biology, Home Range, and Habitat Use of the Brown Wood Rail (Aramides wolfi) in Northwest Ecuador. The Wilson Journal of Ornithology 123(1): 137-141.

19. Kresnik, R. J., and B. J. Stutchbury. 2014. Space-use strategies of wintering Ovenbirds in Belize: causes and consequences. Journal of Field Ornithology, 85(3), 274-288.

20. Leite, G. A., I. P. Farias, A. L. Gonçalves, J. E. Hawes, and C. A. Peres. 2018. Coarse-and fine-scale patterns of distribution and habitat selection places an Amazonian floodplain curassow in double jeopardy. PeerJ 6: e4617.

21. Lindsey, G. D., W. J. Arendt, J. Kalina, and G. W. Pendleton. 1991. Home range and movements of juvenile Puerto Rican parrots. The Journal of wildlife management 318-322.

22. Lopes, L. E., and M. Â. Marini. 2006. Home range and habitat use by Suiriri affinis and Suiriri islerorum (Aves: Tyrannidae) in the central Brazilian Cerrado. Studies on Neotropical Fauna and Environment 41(2): 87-92.

23. Marques-Santos, F., U. Wischhoff, and M. Rodrigues. 2014. New insights on the rarity of the vulnerable Cinereous Warbling-finch (Aves, Emberizidae) based on density, home range, and habitat selection. Brazilian Journal of Biology 74(4): 795-802.

24. Meyer, C. 2010. Spatial ecology and conservation of the endemic and endangered Red-fronted Macaw (Ara rubrogenys) in the Bolivian Andes. Diploma Thesis, Centre for Nature Conservation, Faculty of Biology Georg-August, University Göttingen

25. Monteiro de Barros, F., M. A. M. Granzinolli, R. J. G. Pereira, and J. C. MottaJunior. 2010. Home range and habitat use by the roadside hawk, Rupornis magnirostris (Gmelin, 1788) (Aves: Falcaniformes) in southeastern Brazil. Journal of Natural History 45(1-2): 65-75.

26. Ortiz-Maciel, S. G., C. Hori-Ochoa, and E. Enkerlin-Hoeflich. 2010. Maroonfronted parrot (Rhynchopsitta terrisi) breeding home range and habitat selection in the northern Sierra Madre Oriental, Mexico. The Wilson Journal of Ornithology 122(3): 513-517. 
27. Pavez, E. F. (2014). Patrón de movimiento de dos cóndores andinos Vultur gryphus (aves: cathartidae) en los andes centrales de chile y argentina. Boletín Chileno de Ornitología 20(1-2): 1-12.

28. Peters, V. E., and N. Nibbelink. 2011. The value of fruit security for the conservation of a neotropical frugivore in human-dominated landscapes. Biodiversity and Conservation 20(9): 2041-2055.

29. Ribon, R., and M. A. Marini. 2016. Small territory sizes and high densities of insectivorous birds in an Atlantic Forest secondary fragment, Brazil. Revista Brasileira de Ornitologia 24: 303-313.

30. Salinas-Melgoza, A., V. Salinas-Melgoza, and T. F. Wright. 2013. Behavioral plasticity of a threatened parrot in human-modified landscapes. Biological Conservation 159: 303-312.

31. Santamaría, M., and A. M. Franco. 1994. Historia natural del paujil Mitu salvini y densidades poblacionales de los cracidos en el Parque Nacional Natural TiniguaAmazonia Colombiana: informe final. Fundacion para la Promocion de la Investigacion y la Tecnologia.

32. Sierra-Franco, D., J. H. Martínez-Guerrero, and M. E. Pereda-Solís. 2019. Patrón de movimientos y ámbito hogareño invernal de aves de pastizal en el noroeste de México. Biotecnia 21(3), 41-47.

33. Stahala, C. 2008. Seasonal movements of the Bahama Parrot (Amazona leucocephala bahamensis) between pine and hardwood forests: Implications for habitat conservation. Ornitologia Neotropical 19: 165-171.

34. Tori, W. P., K. H. Bodawatta, K. Tanager, E. L. Lewis, D. S. Neumeister, \& J. Hogle. 2016. White-crowned manakin (dixiphia pipra) use of space in the ecuadorian amazon. Ornitología Neotropical 27: 145-154.

35. Townsend, J. M., C. C. Rimmer, and K. P. McFarland. 2010. Winter territoriality and spatial behavior of Bicknell's Thrush (Catharus bicknelli) at two ecologically distinct sites in the Dominican Republic. The Auk 127(3): 514-522.

36. Trejo, E., R. McNeil, L. Gonzalo Morales, and P. Lau. 2008. Desplazamientos diarios, área de vivienda y utilización de los hábitats por perdices encrestadas (Colinus cristatus) marcadas con radios, en una sabana de Venezuela. Interciencia, 33(3): 207-212.

37. Uejima, A. M. K., A. L. Boesing, and L. D. Anjos. 2012. Breeding and foraging variation of the Plush-crested Jay (Cyanocorax chrysops) in the brazilian Atlantic Forest. The Wilson Journal of Ornithology 124(1): 87-95.

38. Urios, V., M. P. Donat-Torres, M. Bechard, and M. Ferrer. 2014. Movements of a juvenile Crowned Eagle (Harpyhaliaetus coronatus) tracked by satellite telemetry in central Argentina. Journal of Biological Research-Thessaloniki, 21(1): 12. 